\title{
Wilayah Gerak Earth Hour Menjadi Sarana Pemerintah dan Swasta Meraih Dukungan Publik
}

\author{
Siva Yolla Mardiana \\ Ilmu Pemerintahan, Universitas Sultan Ageng Tirtayasa \\ yollasiva30@gmail.com
}

\begin{abstract}
The purpose of Earth Hour and the World Wide Fund for Nature (WWF) invite people around the world to continue to be a part of the social movement in the field of climate change with one of the energy-saving activities. In their campaign, Earth Hour proved to be a dominant force among other powers, associated with the three pillars of power, between political power and economic power. Environmental issues have become a global issue, a variety of damage that occurs on earth has become a serious concern by many. There are many organizations, communities and also mass movements that are concerned with environmental issues. Earth Hour is a global movement that initially campaigned energy savings with its peak event by turning off the electricity in 60 minutes at the end of March every year. Earth Hour movement spread over 153 countries around the world and 28 cities in Indonesia. The research was the focus in the area of motion Earth Hour; The Political environmental theory which was used in this research is Peterson's theory, those are the government, the private sector and social movement itself. This type of research is a qualitative study using a descriptive study. The researcher obtained data by conducting in personal experience and study literature. Data analysis techniques include data reduction, data display, and conclusion. The Conclusion of this study is in Earth Hour has its own characteristics to do such as lobbying to local authorities, then how to lobbying with other people who have the capability to influence public opinion, cooperate with other NGOs and raise social issues in the community to lobby with the private sector. In this area of movement Earth Hour is used as best as possible by the government and private sector to achieve their interests outside environmental related policy issues.
\end{abstract}

Keywords: environmental politics, social movement, political power, economic power, public discourse.

\begin{abstract}
Abstrak
Tujuan Earth Hour dan World Wide Fund for Nature (WWF) mengundang orang di seluruh dunia untuk terus menjadi bagian dari gerakan sosial di bidang perubahan iklim dengan salah satu kegiatan penghematan energi. Dalam kampanye mereka, Earth Hour terbukti menjadi kekuatan dominan di antara kekuatankekuatan lain, yang terkait dengan tiga pilar kekuatan, antara kekuatan politik dan kekuatan ekonomi. Masalah lingkungan telah menjadi masalah global, berbagai kerusakan
\end{abstract}


yang terjadi di bumi telah menjadi perhatian serius banyak orang. Ada banyak organisasi, komunitas dan juga gerakan massa yang peduli dengan masalah lingkungan. Earth Hour adalah gerakan global yang awalnya mengkampanyekan penyempurnaan energi dengan acara puncaknya dengan mematikan listrik dalam 60 menit pada akhir Maret setiap tahun. Gerakan Earth Hour tersebar di 153 negara di seluruh dunia dan 28 kota di Indonesia. Penelitian ini fokus di bidang gerak Earth Hour; Teori lingkungan politik yang digunakan dalam penelitian ini adalah teori Peterson, yaitu pemerintah, sektor swasta dan gerakan sosial itu sendiri. Jenis penelitian ini adalah penelitian kualitatif dengan menggunakan penelitian deskriptif. Peneliti memperoleh data dengan melakukan pengalaman pribadi dan mempelajari literatur. Teknik analisis data meliputi reduksi data, tampilan data, dan penarikan kesimpulan. Kesimpulan dari penelitian ini adalah di Earth Hour memiliki karakteristik tersendiri untuk melakukan seperti melobi pihak berwenang setempat, kemudian bagaimana melobi dengan orang lain yang memiliki kemampuan untuk mempengaruhi opini publik, bekerja sama dengan LSM lain dan mengangkat masalah sosial di masyarakat untuk melobi dengan sektor swasta. Dalam bidang pergerakan ini Earth Hour digunakan sebaik mungkin oleh pemerintah dan sektor swasta untuk mencapai kepentingan mereka di luar masalah kebijakan terkait lingkungan.

Kata Kunci: politik lingkungan, gerakan sosial, kekuatan politik, kekuatan ekonomi, diskursus publik.

\section{Pendahuluan}

Gerakan sosial bukan merupa kan suatu barang baru lagi dikalangan masyarakat Indonesia. Khususnya anak muda generasi dibawah era 90an yang hidup dan berkembang dengan gerakan sosial terbesar dalam sejarah Negara Indonesia untuk mencapai demokrasi yaitu, gerakan 1998. Di mana gerakan 1998 merupakan aksi mahasiswa turun kejalan dalam rangka mencapai tujuan utama untuk menuntut sang penguasaSoeharto untuk lengser dan diikuti dengan terjadinya perubahan kondisi Negara In donesia menuju Negara demokrasi sepenuhnya. Semenjak gerakan ini di anggap monumental karena berhasil membawa perubahan sosial politik da lam kondisi demokrasi tanah air, tidak salah jika dikatakan semenjak inilah gerakan sosial di Indonesia menjadi suatu sikap yang semakin berkembang dan melebur secara baik dengan ben tuk kebudayaan politik yang ada di In donesia.

Demokrasi yang terus berubah dan berkembang di Indonesia menyebabkan pergerakan masyarakat di Indonesia bukan hanya tentang politik dan Negara saja, hingga dewasa ini gerakan sosial di Indonesia bisa mem bicarakan dari hal umum seperti pendidikan, hingga urusan terkait pribadi seperti menyangkut kegiatan ranjang rumah tangga seseorang. Perubahan yang dilakukan gerakan sosial terbukti ampuh dalam menentukan jalur pemerintah dalam menetapkan suatu kebijakan atau suatu keputusan. Pada tulisan ini akan dengan fokus membahas tentang pergerakan yang dilakukan oleh nonprofit organization yaitu Earth Hour. Earth Hour sendiri merupakan sebuah gerakan sukarela lingkungan yang pertama kali diinisiasikan di Sydney, Australia pada tahun 2007 oleh kerjasama antara WWF, Fairfax Media dan Leo Burnett. Kampanye ini dilaksanakan untuk mengurangi emisi gas rumah kaca di Sydney. Saat itu, lebih dari 2,2 juta oranag dan 2.000 bisnis (perkantoran) melakukan pemadaman (switch off) lampu dan barang elektronik lainnya secara serentak selama satu jam, 
mulai dari pukul 20.3021.30 waktu setem pat. Tahuntahun berikutnya, Earth Hour, dibawah nauangan WWF, terus berkembang sebagai kampanye global yang terkonsentrasi pada bidang gaya hidup hemat energy dan ramah lingkungan untuk mencegah perubahan iklim. Selebrasi switch off dil aksanakan pada Sabtu terakhir di bu lan Maret setiap bulannya.

Hingga saat ini, WWF Indone sia terus berupaya mengembangkan kampanye Earth Hour, terutama di kotakota besar seperti Jakarta, Surabaya, Medan, Makassar, Kalimantan hingga Papua. Dimana kotakota besar seperti Jakarta merupakan konsumen akses listrik dengan kapasitas sangat besar. Selain melakukan kampanye secara langsung, Pada tahun 2011 kampanye online Earth Hour Indone sia berhasil menjadi kampanye terbesar di dunia, setelah Brazil dan Amerika. Pada tahuyn 2015, lebih dari 40 kota dari seluruh Indonesia ikut berpartisipasi dalam selebrasi dan didukung oleh komitmen dari berbagai public figure lokal dan nasional. Dalam pelaksanaan Earth Hour, komunitas atau organisasi ini mengajak seluruh lapisan masyarakat, mulai dari sesame komunitas, pelajar, mahasiswa, rumah tangga, pemerinta han, media massa hingga bisnis dan koorporasi untuk bersamasama ber sinergis menjalankan aksi. Aksi Earth Hour sendiri tidak hanya sekedar sim bolis belaka, tetapi juga menjadi gerakan perubahan bersama untuk bumi yang lebih lestari. Selain switch off selama selebrasi, perubahan yang juga diharapkan terwujud pada sektor lingkungan lain seperti penggunaan moda transportasi publik, daur ulangsampah, hemat kertas dan pengu rangan penggunaan plastik sebagai bu daya hidup bijak lingkungan.

\section{Kerangka Teori}

(Peterson, 2000; Bryant, 1992; Vayda, 1983; Blaikie dan Brookfield, 1987; Abe Kenichi, 2003) mengemukakan definisi yang berbeda tentang Politik Lingkungan. Dimana Peterson sendiri mengatakan bahwa politik lingkungan adalah suatu pendekatan yang meng gabungkan masalah lingkungan dengan politik ekonomi untuk mewakili suatu pergantian tensi yang dinamik anatara lingkungan dan manusia, dan antara kelompok yang bermacammacam di dalam masyara kat dalam skala dari individu lokal kepada transnasional secara keseluruhan. (Herman, Hidayat, 2011: 9). Ilmu lain mendefinisikan politik lingkungan adalah sebagai suatu bingkai untuk memahami kompleksitas saling berhubungan antara masyarakat lokal, nasional, politik ekonomi global dan ekosistem (Hikmawan \& Hidayat, 2016). Konsep ini telah diangkat dalam cara yang beraneka seperti "DuniaKetiga Politik Lingkungan", politik lingkungan boleh didefinisikan sebagai usaha untuk memahami sum bersumber politik, kondisi dan men jadi suatau jaringan dari pergantian lingkungan. Pemahaman terkini poli tik lingkungan adalah cenderung unttuk melihat mendalam dinamika lingkungan dan memfokuskan atas suatu susunan sistem manusia. Abe Kenichi mendefinisikan politik lingkungan sebagai suatu kolektif nama untuk semua usaha intelektual untuk secara kritis menganalisis masalah ketepatan sumber daya alam dan asal usul kerusukan sumberdaya secara politik ekonomi (Hikmawan \& Hidayat, 2016), dengan maksud itu diperoleh studi akedemik atau aplikasi yang bersifat praktis. Dalam pengertian lain politik lingkungan peduli pada dimensi politik dalam penggunaan dan pemanfaatan sumberdaya alam. Jelaslah, bahwa lingkup dari politik lingkungan telah merujuk sebagai suatu metode analisis daripada disiplin ilmu pengetahuan yang menyatu atau subdisiplin, yang biasanya diwarnai oleh rangkuman gagasan yang berhubungan, premis dan teori. (Herman, Hidayat, 2011: 910). Istilah ekologi politik secara etimologis berasal dari dua kata, yaitu ekologi dan politik. Ekologi di sini difokuskan pada konteks sumberdaya alam. Artinya membahas ekologi be rarti membahas sumberdaya alam. Sementara itu, istilah politik pada konteksini berarti "kekuasaan" (Hikmawan, 2017a).

Oleh karena itu secara sederhana ekologi politik mencermati persoalan sumberdaya alam sebagai persoalan sosial politik. Senada dengan pengertian sederhana tersebut, Bryant dan Bailey menjelasklan bahwa ekologi politik fokus pada usaha mempelajari sumber, 
kondisi, dan implikasi politik dari perubahan lingkungan hidup. Menurut Bryant asumsi pokok ekologi politik ialah perubahan lingkungan tidak bersifat netral, tetapi merupakan suatu bentuk politik lingkungan yang ban yak melibatkan aktoraktor yang berkepentingan baik pada tingkat lokal, regional, maupun global. Politik lingkungan hdiup merupakan kajian yang membahas interaksi antar berbagai elemen sistem (variable) di dalam proses perumusan dan pengambilan keputusan public yang menuju terbentuknya public policy terhadap masalahmasalah lingkungan. Secara komperhensif dibahas berbagai isu krisis lingkungan, ideologi politik lingkungan, gerakan lingkungan, sistem politik, partai politik dan lingkungan dan proses politik dan lingkungan (Hikmawan, 2017b). Singkatnya, politik lingkungan hidup secara sederhana, mem injam istilah Bryant dan Bailey dimak nai sebagai bidang kajian dalam ilmu politik terhadap masalahmasalah lingkungan.

Kerangka pemikiran adalah bagian yang dapat menggambarkan alur pemikiran penelitian dalam memberikan penjelasan kepada orang lain tentang apa maksud dari penyusunan jurnal ini. Untuk memecahkan suatu masalah yang jelas, sistematis dan terarah diperlukan teori yang mendukung. Untuk itu perlu disusun teori atau model yang digunakan dari sudut mana masalah yang telah dipilih akan disoroti. Dalam karya tulis ini, peneliti menggunakan fokus pada definisi Politik Lingkungan yang dikemukakan oleh Peterson sebagai tolak ukur dalam melakukan penelitian sehingga tidak melenceng. Dimana pada definisi Politik Lingkungan ini menjelaskan bahwa Politik Lingkungan adalah politik ekonomi untuk mewakili suatu pergantian tensi yang dinamik antara lingkungan dan manusia, dan antara kelompok yang bermacammacam di dalam masyarakat dalam skala dari individu lokal kepada transnasional secara keseluruhan. Dapat disimpulkan bahwa Politik Lingkungan tersusun dari masalah Politik yang berhubungan dengan Ekonomi (Hikmawan \& Hidayat, 2016), Kelompok dan Lingkungan. Maka pada pembahasan karya tulis inipula penulis akan menghubungkan antara Gerakan Sosial, Pemerintah dan Pihak Swasta yang menyusun Politik Lingkungan.

\section{Metode Penelitian}

Penelitian ini menggunakan metode deskriptif dengan pendekatan kualitatif. Data yang digunakan dalam penelitian ini merupakan data yang didapatkan sebagai salah satu pengurus tetap pada komunitas Earth Hour Tangerang selama kurun waktu 1 Tahun. Fokus kajian dalam penelitian ini adalah wilayah gerak Earth Hour yang bersangkutan dengan lingkungan yang ternyata tujuan geraknya bukan hanya menyasar masyarakat, melainkan pemerintah sebagai pembuat kebijakan dan sektor swasta sebagai pelaku ekonomi bisnis yang ber pangaruh langsung dengan masyarakat. Dalam menggambarkan wilayah gerak Earth Hour ini maka akan mendapatkan suatu kondisi dimana pejabat publik serta pelaku bisnis semakin berlombalomba untuk menunjukan kepeduliannya pada kegiatan lingkungan. Dengan cara ini juga, akan dilihat seberapa jauh civil society berpengaruh terhadap state dan market. Maka apakah gerakan berbasis sukarelawan peduli lingkungan dianggap sangat relevan dalam menjadi kekuatan baru mendapat dukungan dari pemerintah dan swasta yang membutuhkan dukungan dari publik itu sendiri (Hikmawan \& Hidayat, 2016).

Politik lingkungan adalah sama atas suatu metode terapan oleh ahliahli lingkungan yang menganalisis kebijakan mengenai masalah lingkungan yang relevan, ini yang dikenal dengan sebutan progresive contextualization (kontekstualisasi yang maju). Pendekatan ini memulai dengan aktor (pelaku), dalam hal ini para pemakai sumber daya alam yang langsung, dan mempertim bangkan suatu konteks dengan apa mereka berbuat atau tidak berbuata da lam cara yang khusus terhadap sumberdaya alam. Pendekatan ini juga bermaksud untuk menerangkan mengapa masyarakat menggunakan lingkungan dalam caracara yang khusus, kadang kadang menyebabkan sumberdaya berkurang atau rusak sehingga dapat membahayakan masyarakat dan lingkungan sekitar. (Herman, Hidayat, 2011: 910). 
Karakteristik yang dimiliki oleh kegiatan penyela matan lingkungan dengan usaha penghematan energi ini adalah kegiatan pertama yang sifatnya bukan lah seperti aksi demonstrasi atau yang sifatnya memprotes akan sesuatu yang merusak lingkungan, namun lebih kepada aksi damai pada lingkungan.

\section{Hasil dan Diskusi}

\section{Tiga Pilar Kekuasaan}

Terdapat Tiga pilar kekuasaan yang mengatur kehidupan masyarakat di suatu negara, yaitu kekuasaan negara (state), pasar (market), dan civil society. Negara memiliki political power (kekuasaan politik), pasar memiliki economic power (kekuasaan ekonomi/pasar), dan civil society memiliki social power (kekuatan sosial). Manifestasi dari social power (kekuatan sosial) sendiri adalah gerakan sosial. Relasi antara ketiga pilar kekuasaan tersebut, yakni kekuasaan negara, pasar, dan civil society harus berjalan selaras dan seim bang. (Damsar, 147150). Komponenkomponen tersebut adalah negara atau pemerintahan, pasar atau swasta, dan civil society atau masyarakat sipil yang biasa di wakilkan oleh lembaga swadaya masyarakat terkait. Ketiga komponen ini saling bergantung satu sama lain dalam kehidupan suatu negara. Ketiga komponen ini juga memiliki peran annya masingmasing. Tetapi sering kali hubungan yang ada diantara keti ganya berupa relasi yang saling menguntungkan atau dapat merugikan. Dimana pola hubungan ketiganya digambarkan pada struktur segitiga yang berada disetiap ujungnya. Sebenarnya dapat dillihat dari pola segitiga ini dimana seharusnya negara menjadi peran diatas dan sebagai penyeimbang antara pasar dan civil society. Namun dalam beberapa kasus, seringkali hubungan antara ketiganya berjalan timpang, sehingga yang sering terjadi bukanya sinergisme antara ketiganya melainkan ada elemen yang sangat kuat (dominan) dan sebaliknya ada elemen yang sangat lemah ${ }^{2}$. Kecenderungan praktek dominasi muncul karena menguatnya relasi antara kekuasaan negara dan kekuasaan pasar/korporasi yang banyak meru gikan rakyat.

Masalah lingkungan saat ini menjadi salah satu masalah urgent yang cukup disoroti di berbagai negara. Permasalahan lingkungan yang terjadi bisa disebabkan banyak hal, salah satunya yaitu masalah penguasaan suatu wilayah oleh pihak tertentu contohnya pihak swasta. Penguasaaan ini tentunya mempunyai dampak negatif jika pengelolaannya tidak tepat guna baik bagi lingkungan sekitar dan terlebih masyarakat sekitarnya. Pembiaran penguasaan wila yah ini biasanya memang selalu berdampingan dengan dampak pada kerusakan alam, dan dapat dikatakan dimana menutup akses warga sehingga terjadinya privatisasi ruang publik. Melihat pentingnya hubungan negara, pasar, dan civil society maka makin banyak negara yang mendorong peningkatan peran ketiga pilar ini sebagai perwujudan dari goodgovern ance dimana yang menjadi wacana sebagai sebuah pandangan atau sistem yang dapat mewujudkan sebuah dem okrasi yang murni di Indonesia.

Gambar 1. Segitiga Sinergis Peran antara Negara, Pasar, dan Civil Society.

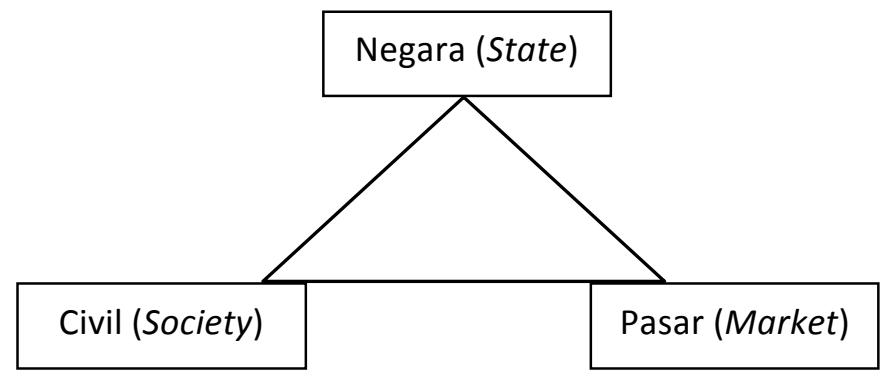

Sumber: Pengantar Sosiologi Politik, 2010: 148. Prof. Dr. Damsar 
Dalam teori tiga pilar ini kita mengetahui bahwa terdapat kekuatan yang dapat menggerakan atau mempengaruhi kehidupan masyarakat. Negara memiliki political power (kekuatan politik) melalui intervensi, pasar memiliki economic power (kekuatan ekonomi) melalui tangan tangan tersembunyinya, sedangkan civil society mempunyai social power (kekuatan sosial) melalui social move ment (gerakan sosial). Agar kesjahteraan, demokrasi, pembangunan ekonomi, hak asasi manusia, dan lingkungan hidup sehat dan berkelanjutan bisa dicapai secara optimal, maka prinsip sinergisitas yang dibangun adalah setiap pilar kekuasaan memberikan kontribusi optimal bagi pencapaian semua tujuan kemanusiaan di atas, baik sebagai individual maupun sebagai kolektivitas. Kontribusi optimal suatu pilar kekuasaan tidak mengham bat pilar lain untuk menyumbangkan secara optimal apa yang seharusnya bisa diberikan. Oleh karena itu, setiap pilar kekuasaan tidak boleh memiliki kekuasaan yang mutlak dan kebebasan tanpa batas. Sebab, bila ada suatu pilar kekuasaan yang memiliki kekusaan mutlak dan kebebeasan tanpa batas, maka ia akan menutup pilar yang lain untuk mencapai nilai optimum dari suatu pencapaian. Beberapa kasus di Indonesia memang lebih banyak kasus yang terjadi ketika kekuatan ekonomi dan poli tik bergabung menjadi suatu kekuasaan yang dominan dan kekuataan sosial menjadi suatukekuasaan yang termarjinalkan. Di mana kasus ini terkait keuntungan kedua belah pihak saja, karena diang gap gerakan sosial terkadang sebagai batu penghalang keuntungan itu tercapai.

\section{Gerakan Sosial dan Perkembangannya di Indonesia}

Gerakan sosial, menurut Singh (2001: 3637), biasanya merupakan mobilisasi untuk menentang Negara dan sistem pemerintahannya, yang tidak selalu menggunakan kekerasan dan pemberontakan bersenjata, sebagaimana pemberontakan, dan revo lusi. Menurutnya, umumnya gerakan sosial menyatakan dirinya di dalam kerangka nilai demokratik. Tarrow (1998:45) mendefinisikan gerakan sosial sebagai tantangan kolektif yang dilakukan sekelompok orang yang memiliki tujuan dan solidaritas yang sama, dalam konteks interaksi yang berkelanjutan dengan kelompok elite, lawan dan penguasa. Disini terdapat empat kata kunci penting, yakni tan tangan kolektif, tujuan bersama, soli daritas sosial, dan interkasi berkelanjutan. Wilson (1973: 911) menekankan "caracara yang tidak melembaga", gerakan ini tidak di tunjukan untuk memperoleh posisipo sisi kekuasaan, tetapi sebagai tawar menawar untuk memengaruhi pem buat kebijakan mengambil solusi yang menguntungkan bagi mereka.

Della Porta dan Diani (1999:1316) menawarkan sedikitnya empat karakteristik utama gerakan sosial, yakni jaringan interkasi informal; perasaaan dan solidaritas bersama; konflik sebagai fokus aksi kolektif, dan mengedepankan bentukben tuk protes. Dengan kata lain gerakan sosial merupakan jaringanjaringan in formal yang mendasarkan diri pada perasaan dan solidaritas bersama, yang bertujuan memobilisasi isuisu konfliktual, melalui berbagai bentuk protes yang dilakukan secara terus menerus. Halhal ini pula yang mem bedakan gerakan sosial yang dil akukan oleh partai politik, kelompok kepentingan, sektesekte agama, protes sesaat, atau koalisi politik sesaat. Pada teori Kebijakan Publik gerakan sosial bisa masuk dalam kelompok kepentingan dan kelompok penekan dalam memainkan peran yang penting untuk mempengaruhi proses pembuatan kebijakan di suatu Negara. Dewasa ini, kita menyaksikan semakin meluasnya gerakan perla wanan masyarakat atau gerakan sosial dalam upaya menentang dan men dorong perubahan kebijakan publik, perubahan politik dan sosial secara luas, baik tingkat lokal, nasional, mau pun global. Di Indonesia, tumbangnya rezim otoritarian Orde Baru Soeharto Mei 1998 tidak dapat dilepaskan dari peran gerakan sosial, yang pada gili rannya menghantarkan bangsa ini ke dalam kondisi yang lebih demokratis (Denny,2006).

Kejatuhan rezim Soekarno dan Soeharto menggambarkan bagaimana kekuatan 
gerakan sosial yang dimiliki oleh civil society mampu mengontrol bahkan menjatuhkan suatu rezim penguasa di Indonesia. Gerakan sosial yang dilakukan oleh civil society untuk menumbangkan rezim orde lama ternyata belum mampu meletakkan fondasi demokrasi dalam Negara. Pada masa orde baru Asosiasi dan organ isasi bergantung pada bantuan finan sial dan akomodasi dari Negara, sehingga mereka bisa disetir sesuai dengan keinginan pemerintah atau menyetirdiri sesuai dengan keinginan penguasa. Setelah itu tidak jauh ber beda gerakan sosial penumbangan re zim orde lama, gerakan sosial penumbangan rezim orde baru juga di gerakan oleh civil society yang berasal dari berbagai asosiasi dan organisasi (Simamora, Hamid, \& Hikmawan, 2019). Pada perkembangannya saat ini Indonesia patut berbangga karena menurut data yang dirilis oleh Global Youth Wellbeing Index yang didirikan bersama mitra dari International Youth Foundation dan Hilton, Indeks yang meneliti tentang tantangan nyata yang dihadapi kaum muda di seluruh dunia yang diharapkan berguna untuk mem berikan informasi dalam membuat masa depan dunia cerah bagi generasi berikutnya, menyatakan bahwa Indo nesia menempati tingkat pertama (51\%) pada Top 25 Countries With Robust Rate of Youth Volunteering yang dirilis pada 13 November 2017 pada halaman Seasia.co Good News from Southeast Asia mengalahkan United States diuruat kedua (46\%), dan Australia di urutan ke tiga (42\%).

"Rich in youthfocused data, the index covers overall picture of the political and civic context for each nation, in cluding the existence of a national youth policy, whether youth feel their government cares about their wants and needs, the age for office, and the rate of youth volunteering. Looking at the area of volunteering, the overall results demonstrate that young people are already directly engaged in solv ing problems their communities face. Extracting the full report of the Index, herewith Seasia provides you with the information on countries that have a very robust rate of youth volunteering. This volunteering rates provide useful insight into the degree of youth en gagement and agency in solving com munity challenges in positive and peaceful ways". (https://sea sia.co/2017/11/13/top25countries withhighrateofyouthvolunteer ing).

Hal ini membuktikan bahwa sukarelawan penggerak gerakan sosial di Indonesia pada perkembangannya saat ini dapat dikatakan sangat meningkat dan tumbuh secara besar. Peran gerakan sosial yang bersifat kolektif atau bersama dapat dikatakan juga sebagai perwujudan budaya gotong royong masyarakat Indonesia yang sudah tertanam dalam kehidupan warga negara dari Indonesia merdeka hingga saat ini.

\section{Lingkungan Sebagai Diskursus Pubik}

Isu lingkungan telah menjadi pilar penting dalam wacana pem bangunan sejak awal 1970an. Bahkan semenjak akhir 1980an soal ini telah menjadi arus utama berbagai kebijakan pembangunan baik tingkat global maupun nasional (Hikmawan \& Hidayat, 2016). Salah satu momen penting yang meletakkan lingkungan sebagai tujuan sekaligus kerangka kerja pembangunan bisa ditemukan dalam laporan World Com mision for Environment and Develop ment, atau lebih dikenal sebagai komisi Brundtland, yang ditugasi Perserikatan BangsaBangsa pada ta hun 1987. Dalam laporan yang ber judul Our Common Future komisi tersebut menggagas konsep Pem bangunan Berkelanjutan (Sustainable Development) yang diarahkan sebagai agenda politik global dengan menem patkan 'pembangunan' dan 'lingkungan' dalam satu kesatuan utuh. Menurut komisi ini pembangunan ha rus mampu mendorong keberlanjutan ekologis dan keadilan global. Dalam laporan ini pembangunan berkelanju tan didefinisikan sebagai "Pem bangunan yang memenuhi kebutuhan kebutuhan 
hari ini tanpa mengor bankan kemampuan generasi menda tang untuk memenuhi kebutuhan kebutuhannya" (World Commision for Environment and Development, 1987). Gagasan ini kembali ditegaskan dalam United Nation Conference of Environment and Development (UNCED) yang diadakan di Rio de Jeneiro, Brasil 1992. Urgensi membahas wacana lingkungan dan pembangunan sebenarnya berangkat dari fakta bahwa lingkungan saat ini sedang tidak pada kondisi yang baik-baik saja dalam perbincangan publik (Hikmawan \& Hidayat, 2016). Hutan makin rusak, laut dan sungai tercemar, iklim makin panas, ozone berlubang, air sulit didapat, udara kotor dll. Konsep tentang alam, lingkungan, manusia beserta hubunganhubungannya yang mendasari pilihan kebijakan tidak bisa dilihat sebagai sesuatu yang alamiah tapi selalu dibentuk melalui gagasan, narasi dan perbincangan (Bryant, 1998; Castree\&Braun, 2001).

Dikutip dari National Geo graphic Indonesia di lamannya na tionalgeographic.co.id, Tiongkok duduk sebagai Negara penghasil emisi terbesar, lebih dari 10.36 miliar ton. India beradi di posisi keempat yang mengeluarkan emisi sebesar 2.4 miliar ton. Sementara itu, Indonesia menghasilkan 2.05 miliar ton emisi, menjadikan Indonesia nomor enam penghasil emisi terbesar. Pemanasan global dan peru bahan iklim yang terusmenerus mem buruk membuat Negaranegara berkumpul membahas tentang isu ini. Dunia dalam hal ini PBB menanggapi isu terkait perubahan iklim secara serius pada konferensi Perubahan Iklim Paris tahun 2015. Sebagai negara yang sudah merasakan bu ruknya dampak perubahan iklim, di mana 63\% Emisi Gas Rumah Kaca In donesia pada tahun 2005 berasal dari perubahan penggunaan lahan dan kebakaran gambut. Sementara 19\% be rasal dari pembakaran bahan bakar fosil. Indonesia berkomitmen pada ta hun 2030 dapat mengurangi 29\% ka dar emisi dengan berbagai upaya sendiri.

Berbagai permasalahan publik yang timbul karena dampak tercemarnya lingkungan memang bukan satu atau dua keluhan saja, tetapi dapat dikatakan memang per maslaahan akibat lingkungan semakin hari semakin berkembang. Mulai dari sungai yang dipenuhi sampah yang mengakibatkan banjir yang menyebar pada pertambahan kasus penyakit bahkan penebangan hutan secara be sarbesaran yang digunakan untuk la han perkebunan yang menyebar pada kasus kurangnya sumber air tanah. Melihat perkembangannya saat ini masyarakat Indonesia dapat dikatakan sebagai Negara yang tingkat kesadaran pada dampak lingkungnnya sudah menuju tahap berkembang. Di mana dapat dilihat dari faktafakta bahwa banyak gerakan sosial yang menuntut pada pemerintah maupun pihak bisnis untuk selalu mementing kan kesejahteraan lingkungan dalam setiap keputusan maupun kebijakan yang hendak diambil. Indonesia sebagai Negara yang kaya akan sumber daya alam memang harus paham kebijakan apa yang seharusnya dil akukan guna memenuhi kebutuhan publik yang bersangkutan dengan lingkungan.

\section{Earth Hour dan Pemerintah}

Keberadaan gerakan sosial tidak dapat dilepaskan dari demokrasi dan ruang publik. Usaha untuk merobo hkan demokrasi hamper selalu berhub ungan dengan usaha untuk meluluh lantahkan ruang lingkup masyarakat sipil. Selanjutnya, mustahil bila mem bicarakan demokrasi tanpa mengiku tsertakan ruang publik. Pelarangan da lam partisipasi menimbulkan kepin cangan bentuk demokrasi. Oleh kare nanya, menurut Chandhoke (2007), demokrasi memiliki hubungna dua sisi dengan ruang publik. Tidak ada demo krasi tanpa ruang publik, namun secara bersamaan, tidak akan ada demokrasi apabila ruang publik tersebut tidak luas dan representatif.

Perlu diperjelas bahwasanya Earth Hour adalah kegiatan yang si fatnya adalah multi stakeholder. Ban yak pihak yang membantu dalam mensukseskan kegiataan tersebut. Dengan banyaknya pihak yang ikut serta dalam acara Earth Hour, tentunya WWF sebagai promotor dari acara ini, melakukan serangkaian Lobbying terhadap pihak yang dianggap memiliki 
kapabilitas untuk mensukseskan kegiatan Earth Hour, WWF memiliki karakteristik tersendiri dalam melakukannya, diantaranya Lobbying terhadap otoritas setempat, terhadap tokoh yang dianggap memiliki kapa bilitas untuk mempengaruhi opini pub lik. Dalam tabel akan terlihat bagaimana WWF selaku penggerak Earth Hour melakukan Lobbying terhadap berbagai pihak yang dianggap memiliki pengaruh yang besar dalam suatu Negara

Tabel 1

Lobbying WWF terhadap NegaraNegara dengan bentuk pemerintahan atau birokrasi terpusat

\begin{tabular}{|l|l|l|l|l|l|l|}
\hline $\begin{array}{l}\text { Goverment } \\
\text { Type }\end{array}$ & State & Year s & NGO's & Privat & $\begin{array}{l}\text { Public } \\
\text { Figure }\end{array}$ & Government \\
\hline $\begin{array}{l}\text { Commun ist } \\
\text { State }\end{array}$ & Vietnam & 2011 & $\begin{array}{l}\text { WWF } \\
\text { Vietnam Local } \\
\text { Partner }\end{array}$ & & $\begin{array}{l}\text { The People's } \\
\text { Committe e of Thua } \\
\text { Thien Hue Province } \\
\text { Mayor of Shanghai } \\
\text { Mayor of Guang zho u }\end{array}$ \\
\hline $\begin{array}{l}\text { Constitut ional } \\
\text { Sultan ate }\end{array}$ & $\begin{array}{l}\text { Brunei } \\
\text { Darus } \\
\text { salam }\end{array}$ & 2010 & & & Odessei Alliance \\
\hline $\begin{array}{l}\text { Constitut ional } \\
\text { Emirate }\end{array}$ & Kwait \\
$\begin{array}{l}\text { Federati on with } \\
\text { specified powers } \\
\text { dele gate d to the } \\
\text { UAE }\end{array}$ & $\begin{array}{l}\text { United } \\
\text { Arab } \\
\text { Emirates }\end{array}$ & 2009 & & & & $\begin{array}{l}\text { Kuwaiti Team for } \\
\text { Global Warming }\end{array}$ \\
\hline
\end{tabular}

Sumber: Jenis pemerintahan tiap Negara pada:

https://www.cia.gov/library/publications/theworldfactbook/dan lobbying pertama kali pada: http://earthhour.org/external_modules/map/map/

Tabel 2.

Lobbying WWF terhadap NegaraNegara dengan Tipe pemerintahan Demokrasi dan Republik*

\begin{tabular}{|c|c|c|c|c|c|c|}
\hline $\begin{array}{l}\begin{array}{l}\text { Govermen } \\
\text { t Type }\end{array} \\
\end{array}$ & State & $\begin{array}{l}\text { Year } \\
\text { s }\end{array}$ & NGO's & Privat & $\begin{array}{l}\text { Public } \\
\text { Figure }\end{array}$ & Government \\
\hline \multirow[t]{4}{*}{$\begin{array}{l}\text { Parliamentay } \\
\text { Democracy }\end{array}$} & Albania & 2009 & ANEP & & & \\
\hline & Aruba & 2009 & \begin{tabular}{|l|} 
Earth \\
Hour \\
Aruba \\
Communit \\
y Group
\end{tabular} & & & $\begin{array}{l}\text { Minister of Social } \\
\text { Affairs, Economy } \\
\text { and Culture }\end{array}$ \\
\hline & Bulgaria & 2009 & $\begin{array}{l}\text { WWF } \\
\text { Bulgaria }\end{array}$ & & & \\
\hline & Canada & 2008 & $\begin{array}{l}\text { WWF } \\
\text { Canada }\end{array}$ & & & Mayor of Toronto \\
\hline $\begin{array}{l}\text { Federal Par } \\
\text { liamentay De } \\
\text { mocracy }\end{array}$ & Australi ia & 2007 & $\begin{array}{l}\text { WWF } \\
\text { Australia }\end{array}$ & $\begin{array}{l}\text { Leo Bur } \\
\text { net } t\end{array}$ & & \\
\hline
\end{tabular}




\begin{tabular}{|c|c|c|c|c|c|c|}
\hline & Belgia & 2008 & $\begin{array}{l}\text { WWF } \\
\text { Belgia }\end{array}$ & & & \\
\hline $\begin{array}{l}\text { Parliame } \\
\text { ntary Consti } \\
\text { tuti onal } \\
\text { Monarchy }\end{array}$ & Lesotho & 2011 & & $\begin{array}{l}\text { Khaya } \\
\text { Holdi n gs }\end{array}$ & & $\begin{array}{l}\text { Minister of } \\
\text { Tourism, Environ } \\
\text { ment and Culture }\end{array}$ \\
\hline \multirow[t]{4}{*}{ Republic } & Chille & 2009 & $\begin{array}{l}\text { WWF } \\
\text { Chile Cam } \\
\text { paign Group }\end{array}$ & & & \\
\hline & Cyprus & 2008 & $\begin{array}{l}\text { Young } \\
\text { Cyprus } \\
\text { Green }\end{array}$ & & & $\begin{array}{l}\text { Cyprus } \\
\text { Green } \\
\text { Party }\end{array}$ \\
\hline & Indone ia & 2009 & $\begin{array}{l}\text { WWF } \\
\text { Campaign } \\
\text { Group }\end{array}$ & & $\begin{array}{l}\text { Nugi e } \\
\text { Charles } \\
\text { Bona r } \\
\text { Sirait }\end{array}$ & $\begin{array}{l}\text { Governor } \\
\text { of Jakarta }\end{array}$ \\
\hline & Sri Lanka & 2010 & & $\begin{array}{l}\text { Expol a nka } \\
\text { Holdi n gs } \\
\text { PLC }\end{array}$ & & $\begin{array}{l}\text { Ministry of } \\
\text { Environment }\end{array}$ \\
\hline & & & & & & \\
\hline
\end{tabular}

Sumber: Jenis pemerintahan tiap negara ada pada: https://www.cia.gov/library/publica tions/theworldfactbook/dan lobbying pertama kali pada: http://earthhour.org/exter nal_modules/map/map/dan dilakukan pengubahan pada data yang diperlukan.

Pada prakteknya di Indonesia hubungan Earth Hour dengan pemerintah dapat dikatakan cukup baik, tetapi juga hubungan tersebut dikondisikan dengan sikap pemerintah daerah yang dapat terbuka atau tidak dengan kegiatan seeperti Earth Hour ini. Contohnya pada kegiatan Earth Hour 2018, Kota Bandung adalah sa lah satu kota yang menggelar aksi Switch off tersukses di Indonesia, hal ini akibat adanya bentuk dorongan dari pemerintah daerah setempat yang mendukung kegiatan dengan menge luarkan surat himbauan kepada masyarakat. Bukan hanya di Bandung, Pemerintah Kota Makassar juga tidak ketinggalan untuk mendukung dengan melakukan himbawan secara langsung melalui video ajakan kampanye switch off.

Di Indonesia sendiri switch off berpusat di Stadion Gelora Bung Karno, kegiatan inipun tidak luput dari dukungan Gubernur DKI Jakarta yaitu Anies Baswedan. Tapi sangat disa yangkan pada pemerintah provinsi Banten sampai pada selebrasi tahun 2018 belum juga menyatakan dukungan terhadap kegiatan peduli lingkungan Earth Hour ini. Selain dari kepala daerah yang mendukung acara ini, Earth Hour pun memiliki hub ungan baik dengan Kementrian Lingkungan Hidup dan Kementrian Energi dan Sumber Daya di Negara berkem bang yang menganut sistem pemerintahan yang demokrasi seperti di Indonesia, gerakan sosial mempu nyai peran dan fungsi untuk 'memper temukan kepentingan' warga dengan aktor pembuat atau perumus kebijakan yaitu pemerintah. Sehingga peran gerakan sosial menjadi penekan yang akan memberikan informasi kepada bejabat publik terkait kemungkinan dan akibat yang akan diambil dalam suatu usulan kebijakan formal.

\section{Earth Hour dan Pihak Swasta}


Hubungan antara pihak swasta dan gerakan sosial bisa bersifat saling mempengaruhi. Pihak swasta dan gerakan sosial, dalam prespektif lib eral, memiliki karakteristik yang sama, yaitu otonom, bebas, dan man diri. Oleh karenaa itu, hubungan pihak swasta dengan gerakan sosial saling mengutakan dan saling meneguhkan satu sama lain terhadap keberadaan mereka masingmasing. Namun ketika pasar dipandang terlalu serakah dan menimbulkan dampak negatif terhadap kesejahteraan umat manusia, civil society melalui gerakan sosial dapat bersifat oposisi terhadap pihak swasta sebagai kekuatan ekonomi. Earth Hour dalam melaksanakan kegiatannya selain bekerja sama dengan pihak pemerinta han, juga bekerjasama dengan pihak swasta. Dalam melakukan Lobbying terhadap pihak swasta, WWF mampu membawa ide bahwasannya Earth Hour sebagai salah satu bentuk CSR (Corporate Social Responsibility) sebagai komitmen atas upaya pelestarian lingkungan dan menunjukkanb bah wasannya dengan turut serta dan ambil bagian dalam kegiatan Earth Hour, be rarti perusahaan tersebut memiliki komitmen terhadap lingkungan. Pada pagerlaran kegiatan Earth Hour per tama kali di Sydney, WWF sudah melakukan serangkaian Lobbying dan kerjasama dengan pihak swasta yakni perusahaan jada periklanan Leo Bur nett dan juga berbagai perusahaan dan toko di pusat kota Sydney. Pernanan pihak swasta ini dibutuhkan selain sebagai mitra kerjasama, juga digunakan sebagai tempat untuk mengumpulkan dana yang akan dipakai dalam malam puncak kegiatan Earth Hour. Cara yang dilakukan WWF untuk menarik perhatian dari berbagai pihak swasta adalah dengan cara mengedepankan opini bahwasanya Earth Hour adalah suatu alternatif CSR dari sebuah perusahaan, selain itu WWF juga mempublikasikan apa yang yang dilakukan oleh para perus ahaan tersebut di situs resmi mereka sehingga "publik akan tahu apa yang anda lakukan".

\section{Kesimpulan}

Sebagai sebuah gerakan sosial, tentunya gerakan Earth Hour dituntut untuk tetap konsisten di dalam men jalankan idealisme utamanya yakni hemat energi penerapan pada kehidupan seharihari dan peduli terhadap lingkungan didalam menghadapi kebijakan Negara yang kadang cenderung tak berpihak pada kondisi sosial lingkungan. Gerakan Earth Hour adalah acara yang dalam pelaksanaanya membutuhkan banyak audience oleh karena itu penting dil akukan upayaupaya persuasif untuk menunjukan bahwasanya kegiatan ini mudah untuk dilaksanakan, dan dalam penerapannya memiliki karakteristik tertentu. Karakteristik yang dimiliki oleh kegiatan penyelamatan lingkungan dengan usaha penghematan energi ini adalah kegiatan yang si fatnya bukan seperti aksi demonstrasi atau yang sifatnya memprotes akan sesuatu yang merusak lingkungan, na mun lebih kepada aksi damai peduli lingkungan.

Perlu diperjelas, bahwasanya Earth Hour adalah kegiatan yang si fatnya multi stakeholder banyak pihak yang membantu dalam mensukseskan kegiatan ini. Dengan banyaknya pihak yang ikut serta dalam acara Earth Hour tentunya banyak serangkaian Lobby ing terhadap berbagai pihak yang di anggap kapabilitas untuk mensukses kan kegiatan Earth Hour. Dimana Earth Hour memiliki karakteristik tersendiri untuk melakukannya dian taranya yakni Lobbying terhadap otoritas setempat, lalu cara yang dil akukan dengan melobi terhadap tokoh yang dianggap memiliki kapa bilitas untuk mempengaruhi opini publik, bekerjasama dengan NGO lain dan mengangkat isuisu sosial di masyarakat hingga melakukan lobby ing dengan pihak swasta. Hal ini san gat menjadi catatan penting ketika da lam wilayah gerak Earth Hour yang seharusnya ini, akan timbul beberapa konteks hubungan baru antara Gerakan sosial dengan penggiringa opini publik terhadap suatu isu yang akhirnya hanya akan menguntungkan beberapa pihak dan memicu permasa lahan lingkungan yang dipolitisasi baik 
dari pihak pemerintah maupun swasta. Permasalahan lingkungan yang menjadi fokus utama gerakan Earth Hour merupakan suatu sarana yang empuk bagi para aktor publik untuk mengambil dukungan baik dalam segi komersil maupun segi tingkat kepercayaan masyarakat. Sarana yang empuk ini juga dimaksudkan ketika kepentingankepentingan beberapa pihak menjadi tujuan utama terseleng garanya suatu kegiatan dibandingkan dengan tujuan untuk menjaga keles tarian lingkungan dan menghemat en ergi. Maka dengan ini penulis dapat dengan jelas menyimpulkan bahwa permasalahan lingkungan bukan suatu kendaraan yang dapat dengan mu dahnya digunakan sebagai transportasi atau cara beberapa pihak guna men capai kepentingannya lebih dari itu permasalahan lingkungan merupakan suatu isu yang serius dan penting untuk diperhatikan lebih lanjut baik dari masyarakat, hingga sektor pemerintah maupun sektor swasta.

\section{Referensi}

Agustino, Leo. 2016. Dasardasar Kebijakan Publik. Bandung: Alfabeta.

Bakhtiar, Rizal. 2015. Analisis Meng globalnya Kegiatan Earth Hour Tahun 20172012. Sura baya: Universitas Airlangga.

Damsar. 2010. Pengantar Sosiologi Politik. Jakarta: Prenadamedia Group

Hardjono, Susilo. 2008. Eksistensi Gerakan Greenpeace di Indo nesia. Yogyakarta. Jurnal Online diakses pada 23 Mei 2018.

Herman, Hidayat. 2011. Politik Lingkungan: Pengelolaan Hutan Masa Orde Baru dan Refor masi. Jakarta: Yayasan Pustaka Obor Indonesia.

Hiariej, Eric and Kristian Stokke. 2017. Politics of Citizenshipin Indonesia. Jakarta: Yayasan Pustaka Obor Indonesia in co operation with PolGov Fisipol UGM and University of Oslo.

Hikmawan, M. D. (2017a). Pluralisme Demokrasi Politik di Indonesia. Journal of Governance, 2(2), 223-247. https://doi.org/http://dx.doi.org/10.31506/jog.v2i2.2678

Hikmawan, M. D. (2017b). Politik Perbedaan: Minnoritas dalam Implementasi Kebijakan. Journal of Indonesian Public Administration and Governance Studies (JIPAGS), 1(1), 88-98.

Hikmawan, M. D., \& Hidayat, R. (2016). Depoliticisation of Public Issue : Low Degree of Government ' S Democratic Legitimacy. Journal of Governance, 1(1), 23-37. https:// doi.org/http://dx.doi.org/10.31506/jog.v1i1.1311

https:// seasia.co. 2017. Top 25 Countries with high rate of youth volunteering. Pada 24 Mei 2018.

https:/ / www.cia.gov/lbrary/pu blications/theworldfactbook/ dan lobbying pertama kali pada: http:/ / earthhour.org/ex ternal_modules/map/map/.

https://www.cia.gov/li brary/publications/theworld factbook/ dan lobbying per tamakali pada: http://earthhour.org/exter nal_modules/map/map/dan dilakukan pengubahan pada data yang diperlukan 
Jae, Lee See. 2000. Environmental Movement in Korea and Its Political Empowerment. Ko rea: Korean Journal/Autumn. Jurnal Online diakses pada 25 Mei 2018.

Male, John Van and Leo d'Anjou. 1998. Between Old and New: Social Movements and Cul tural Change. Jurnal Online diakses pada 25 Mei 2018.

Marwuri, Trilis. 2016. Komunkasi Persuasif Komunitas Earth Hour dalam Membentuk Per ilaku Ramah Lingkungan pada Masyarakat Kota Pekanbaru. Pekanbaru: JOM FISIP Bina Widya.

Rusmanti, Joni. 2012. Gerakan Sosial, Sejarah Perkembangan Teori antara Kekuatan dan Kelema han. Universitas Palangka Raya. Buku Online diakses pada 20 Mei 2018.

Simamora, A. R., Hamid, A., \& Hikmawan, M. D. (2019). Diskriminasi Terhadap Kelompok Minoritas Jemaat Ahmadiyah Indonesia (JAI) di Tangerang Selatan. International Journal of Demos, 1(1), 19-37. Retrieved from http:/ / hkpublishing.id/ijd-demos

Ulfa, Ghina Shabrina. 2017. Efektivi tas Instagram Earth Hour Bo gor Sebagai Media Kampanye Lingkungan. Bogor: Departement Sains Komunikasi dan Pengembangan Masyarakat Fakultas Ekologi Manusia In stitut Pertanian Bogor. Jurnal Online diakses pada 25 Mei 2018.

Widorini, Wahyu Yuliastuti. 2014. Strategi Komunikasi Earth Hour dalam Kampanye Gaya Hidup Ramah Lingkungan. Surakarta: Universitas Sebelas Maret.

www.wordwildlife.org. Pada 23 Mei 2018

www.wwf.co.id. Pada 23 Mei 2018.

www.earthhour.org. Pada 23 Mei 2018.

www.greenpeace.org. Pada 23 Mei 2018.

www.walhi.or.if. Pada 23 Mei 2018. 